\title{
FIRST STEPS - a randomized controlled trial on the evaluation of the implementation and effectiveness of two early prevention programs for promoting the social integration and a healthy development of children with an immigrant background from $0-3$
}

Judith Lebiger-Vogel ${ }^{1}$, Constanze Rickmeyer ${ }^{1}$, Annette Busse ${ }^{1}$, Korinna Fritzemeyer ${ }^{1}$, Bernhard Rüger ${ }^{2}$ and Marianne Leuzinger-Bohleber ${ }^{1 *}$

\footnotetext{
Abstract

Background: The social integration of children with an immigrant background has become one of the most urgent social responsibilities in Germany. They are more likely to live in high-risk environments and are disadvantaged with respect to health related variables as well as educationally. Quite a number of projects supporting their integration into the German society exist although many are hardly scientifically evaluated. Most of them focus on the acquisition of German language and therefore address older children (and adults). However, international experts agree that social integration is not only a matter of language but also of earlier developmental processes of children in their first months of life connected to adequate early parenting.

Methods/Design: The model project FIRST STEPS focuses on earliest prevention for children with an immigrant background, supporting their parents in the critical phase of migration and early parenthood. In a prospective randomized comparison group design the effectiveness of a psychoanalytically oriented early prevention program (intervention A) is compared to the outcomes of groups offered by paraprofessionals with an immigrant background (intervention B). Intervention A is a professional offer supporting immigrant families based on developmental psychological and on knowledge on early parenting. 180 families are randomly assigned to intervention A or B. They are supported during the first 3 years of the children's lives. Social and family stressors, the quality of the parent-childinteraction, child attachment security, the affective, cognitive and social-emotional development of the children and the social integration of the families are assessed during and after the intervention.

(Continued on next page)
}

\footnotetext{
* Correspondence: m.leuzinger-bohleber@sigmund-freud-institut.de

${ }^{1}$ Sigmund-Freud-Institut, Frankfurt/Main, Germany, University of Kassel, Kassel,

Germany

Full list of author information is available at the end of the article
} 
(Continued from previous page)

Discussion: The project aims at evaluating the implementation as well as the short- and long-term effectiveness of psychoanalytically oriented intervention A compared to the outcomes of intervention B. It is expected that professionally supported early parenting (intervention A) improves the social-emotional, cognitive and language development of immigrant children as well as the social integration of their families to a greater extent than in the comparison groups. In case the model project proves to be effective, a rollout across Germany is possible. Due to the "difficult-to-reach" immigrant families challenges in recruitment, uptake and retention of participants are anticipated.

Trial registration: DRKS-ID: DRKS00004632, trial registration date: 05.02.2013

Keywords: Psychoanalysis, Early prevention, Immigrant background, Migration, Integration, Parent-childrelationship, Early parenting, Attachment, Child development

\section{Background}

Children with an immigrant background are still disadvantaged concerning health related variables such as obesity or psychopathological problems (Kurth \& Schaffrath Rosario 2007; Hölling et al. 2008; Rattay et al. 2012; https://www.bmas.de/SharedDocs/Downloads/DE/ PDF-Publikationen-DinA4/a334-4-armuts-reichtumsbericht-2013.pdf?__blob=publicationFile; Autorengruppe Bildungsberichterstattung 2012), their educational achievement and are more likely to live in high-risk environments (Sachverständigenrat deutscher Stiftungen für Integration und Migration (SVR) GmbH: Deutschlands Wandel zum modernen Einwanderungsland. Jahresgutachten 2014; Leuzinger-Bohleber et al. 2006; Leuzinger-Bohleber et al. 2009; Leuzinger-Bohleber et al. 2011). ${ }^{1}$ However, it is not the immigrant background per se that puts these children at risk of becoming disadvantaged but it is rather the factors that are associated with their parents' migration, psychological factors due to the different phases of migration and socio-economic factors (low socio-economic status, unemployment, insecure institutional status etc.) that create difficult developmental environments for these children. Children of mothers who have not lived in Germany for a long time are particularly disadvantaged, because the mothers are in an emotionally insecure situation themselves. They have to get along in a new surrounding while not having experienced attachment figures - such as their own parents and siblings - at reach for support. Especially during the vulnerable time after the birth of a child the mothers often feel alone and isolated and the risks of social withdrawal, isolation and depression are significant. The mother's stress can have a negative impact on the emotional quality of the early mother-child relationship and attachment security and thus brings about an additional disadvantage for the children, placing them in a special risk group among the immigrant population. Results of the Frankfurt prevention study (LeuzingerBohleber et al. 2006; Leuzinger-Bohleber et al. 2009; Leuzinger-Bohleber et al. 2011) indicated that a poor or lacking early integration can be associated with a potential disruption of "natural attachment" in the course of migration and young motherhood.

In addition we know that if children - closely attached to their primary caregivers - unconsciously notice that their parents, especially their mother, suffer from severe homesickness or have not really "arrived" in the country of immigration emotionally, they will perceive turning to the culture and language of the immigration country as a betrayal and a turning away from their parents or mother. Often this kind of loyalty conflict keeps children with an immigrant background from successfully learning the language of the immigration country and integrating psychosocially (King 2007; Leuzinger-Bohleber 2009). Unconsciously they identify with their parents' losses possibly leading to behavioural difficulties, school failure and/or depression if not processed thoroughly.

Especially findings from attachment research regarding disorganized attached children (Type D) are alarming. As known from longitudinal studies, children who show this kind of attachment style have the worst prognosis and will show aggressive-destructive behaviour, worse school achievement and massive psychological problems already during elementary school in all probability if they do not receive early help and support (Lyons-Ruth et al. 1993; Solomon et al. 1995; Green and Goldwyn 2002; Moss et al. 2004; Cassidy and Shaver 2008; Stacks and Oshio 2009). A notable number of these children come from families with an immigrant background, who due to factors which are often associated with migration such as experiences of violence in their home country, social isolation after marriage migration and resp. low socialeconomic status are severely stressed or even traumatized (Batista-Pinto Wiese 2010; Fazel et al. 2005; LeuzingerBohleber 2012; Schechter and Rusconi Serpa 2014).

Quite a number of projects, which promote the social integration of children with an immigrant background exist in Germany. Most of them focus on acquiring the German language and thus address older children or adults (Friedrich and Siegert 2009; Lösel et al. 2006) and do not explicitly take into account the children's well- 
being. Infants however, only begin to actively acquire language during their second year of life and during infancy learning their mother's language is most important. It is well known that the development of language is based on early "embodied" and preverbal relationships from the beginning on. Stern (1985) studied the different stages of the development of the self and showed that the "verbal self" in the second year of life is built upon the earlier stages of this development (the emergent self, the core self etc.). Thus integration approaches, which solely focus on acquiring the German language, are limited to this aspect and are not effective for children between the age of zero and three (infants and toddlers).

Some of the already existing projects supporting children with an immigrant background have been evaluated. The quality of these evaluations can however often be regarded as problematic and the effectiveness of programs conducted by lay helpers with an immigrant background has often not been thoroughly explored (Friedrich and Siegert 2009; Lösel et al. 2006). In addition many projects deploy lay helpers although the outcome of early prevention projects seems to be positively influenced by the professionalism of staff (Olds et al. 2008; Holodynski et al. 2007). Systematic integration projects with the goal to optimize the first environmental and relationship experiences of children with an immigrant background are scarcely evident in Germany. However research findings strongly suggest such an approach, because infants, who grow up in a positive and emotionally secure environment are more creative, show less aggression, show better cognitive, affective and social-emotional development and learn languages more easily (Aviezer et al. 2002; DeKlyen and Greenberg 2008; Fearon et al. 2010; Sroufe et al. 2005; Thompson 2008; Van IJzendoorn et al. 1995). Therefore one can assume that approaches which take early relationships within the direct living environment as a starting point (during this age particularly the core family), could also improve integration of children with an immigrant background during infancy and toddler age. Furthermore, language acquisition as well as the development of communicative, social competencies cannot fully be understood if they are not viewed within the context of early relationship experiences (Emde and Leuzinger-Bohleber 2014; Korntheuer et al. 2010).

FIRST STEPS is a psychoanalytically oriented prevention program for immigrant families offered from the time of pregnancy until entering kindergarten. It focuses on the specific challenges and needs of families with an immigrant background and seeks to optimize the early developmental environment of children at risk of growing up disadvantaged due to their parents' acute migration (and possible stress).

The project was conceptualized in the context of the $\mathrm{IDeA}^{2}$ Center and is implemented by the Sigmund-
Freud-Institut (SFI; Frankfurt/Main) in collaboration with the Anna-Freud-Institut (Frankfurt/Main). IDeA represents a large, interdisciplinary research center, a cooperation between the Goethe University Frankfurt, the German Institute for International Educational Research (DIPF) and the SFI. ${ }^{3}$ It was established within the framework of the LOEWE ${ }^{4}$ initiative, a large promotional programme fostering excellent research in the federal state of Hessen, Germany. FIRST STEPS serves as a scientifically evaluated model project in the sense that its success would enable the implementation in other communities and cities in Germany, independently from regional specificities such as the ethnic composition of the immigration population, project staff and context of recruitment. In a second step it is planned to also implement FIRST STEPS in Berlin. This offers the opportunity of testing the workability and practicality of dissemination, recruitment strategies and possible needs for adaption of FIRST STEPS in another institutional context.

\section{Goals of FIRST STEPS}

FIRST STEPS seeks to contribute to early prevention and improving the social integration as well as a healthy development of children coming from social marginal groups of society, which are hard-to-reach (see below). In supporting mothers with an immigrant background and in promoting infant-mother (and father) relationships from its earliest point on - pregnancy - we hope that FIRST STEPS will facilitate successful parent-child interaction from the time the natural window for its development opens. In doing so, the project intends to promote attachment security and a positive child development. As empirical attachment, neurobiological and epigenetic research show, attachment security is a protective factor for cognitive, socio-emotional and language development as well as academic success (Berlin et al. 2008). Furthermore, it is expected that by promoting parents' reflective functioning (Fonagy et al. 2002), adequate emotion regulation, processing of losses caused by migration, parenting behaviour (e.g. responding to their infant's cues consistently) as well as cultural competencies parents' and children's psychosocial integration will be facilitated. Negative primary (e.g. poorly educated parents) and secondary family background related effects on the child (Boudon 1974, e.g. parental educational decisions when poorly informed about or afraid of the educational system) would be weakened by this kind of support.

In a prospective randomized comparison group design the project aims at evaluating the implementation as well as the short- and long-term effectiveness of FIRST STEPS (intervention A) in comparison to an intervention being offered by paraprofessionals (intervention B). 
A variety of instruments are applied at different times of measurement during the intervention as well as afterwards when the children attend kindergarten (follow-up; see below).

\section{Methods/Design}

Participants, inclusion and exclusion criteria

FIRST STEPS addresses pregnant first-generation immigrant women (from the second trimester on, and their husbands) who have no or little knowledge of the German language and have not been living in Germany for longer than 3 years (in accordance with the population of the integration courses, see Rother N, http://www.bamf.de/ SharedDocs/Anlagen/DE/Publikationen/WorkingPapers/ wp19-Integrationspanel.pdf?_blob=publicationFile). Most of our participants have a low socio-economic status and are hard-to-reach. In this context "hard-to-reach" means the participants often fail to access social and community services (e.g. family support services) and therefore remain unprovided (Doherty et al. 2004). It is difficult to recruit this population and a lot of effort is needed to get the participants to commit to the prevention program and to stay involved over time (Cooney et al. 2007).

\section{Recruitment}

Participants are recruited in obligatory integration courses (on German language and "culture") at three different regional non-profit social service centres in Frankfurt/Main. These courses were implemented nationwide in 2004 and are part of the political reactions to the clarion call of the early PISA studies and the late realization that Germany has become an immigration country but had mainly missed out on socially integrating its immigrants.

\section{Interventions/observational groups}

The FIRST STEPS study compares two prevention programs which are both offered from the time of pregnancy until entering kindergarten: A broader, more individual and complex psychoanalytically oriented intervention, the FIRST STEPS intervention (A) and a a less complex standard intervention being offered by paraprofessionals (B).

\section{Intervention A - FIRST STEPS}

The psychoanalytically trained FIRST STEPS project staff, mostly mothers with an immigrant background themselves, support the women (and their husbands) ideally already during pregnancy. Hence they build an emotional relationship with them in order to continue their support after the birth of the child. This support should help the women to avoid withdrawal into isolation. Afterwards the project staffs continue to accompany and support mothers and children both in group contacts (moderated weekly groups with two project staff members) and individual contacts (via telephone, home visits) until the children enter kindergarten at the age of around three. The FIRST STEPS approach is curriculum-based. The training of the project staff includes psychoanalytic case-supervision, practice reflection with the coordinator of the practical implementation $^{5}$ as well as regular supervision with child and adolescent psychotherapists. The manualised curriculum, which has been developed by the coordinator of the practical implementation, is based on psychoanalytic and empirical developmental psychology and will be published in the near feature. The conceptualisations closely refer to other already evaluated psychoanalytically oriented parenting programs (Emde and Robinson 2000; Meurs et al. 2006; Parens et al. 1995). The training sensitizes staff for the processes of transference and counter-transference allowing for a deeper understanding of the women's situation and children's needs. The project staffs learn to develop a psychoanalytical "mindset" and to create a holding and containing function (Bion 1963) in contact with the individual women as well as during the group sessions. Thus they can serve as role models and as a "secure base" (Bowlby 1969, p. 325) for the mothers, supporting them in the vulnerable phase of their early motherhood. Their consultation focuses on individual needs of the mothers and children as well as questions and concerns the families might have concerning the child's development. The project staff thereby supports parenting competences (e.g. reflective functioning, adequate emotion regulation). Furthermore, questions concerning migration problems of the families (supporting them to consult institutions, clinics, social and mental health care services, language courses, educational institutions etc.) are addressed. Coping with losses associated with the women's and families' migration is supported.

\section{Intervention $B$}

The mothers and children in intervention B take part in self-organized open "mother-child groups" led by female paraprofessionals with an immigrant background ${ }^{6}$, who are mostly mothers themselves, pass on their experiences to the mothers and invite for social exchange. The paraprofessionals are only instructed and informed about the study very basically, including the aimed duration of the intervention until children enter kindergarten and research instruments, and are free to conduct and organize their groups according to their views and their experience as immigrants and mothers. They do not receive any support with regard to contents and have no contact with the project organization and 
implementation other than with the research team collecting data about mothers and children.

\section{Assessments}

A variety of instruments are applied at five different times of measurement; four in the course of the intervention, one directly afterwards, when the children enter kindergarten ( $\mathrm{t} 2$ : 2,5-5 months, $\mathrm{t} 3$ : $13-15$ months, $\mathrm{t} 4$ : 24-27 months, t5: $36-39$ months) and one time of measurement after the intervention, when the children attend kindergarten (t6: 8-14 months after kindergarten entrance).

Sociodemographic information of the families (baseline assessment, $\mathrm{t} 1$ ) is assessed at the beginning of the intervention by using a self-report questionnaire, which was developed by the Bundesamt für Migration und Flüchtlinge (BAMF, German Federal Office for Migration and Refugees). ${ }^{7}$ The BAMF questionnaire is complemented by an additional set of questions concerning the mother's integration called the Hertie Belonging Scale, a scale developed by the research team. Furthermore, the project staff evaluates family stressors and social support of the families during the course of the intervention by using the Heidelberger Belastungsskala (HBS-L) (Stasch 2009), a standardized screening scale. In addition the mothers' subjective daily stressors and life-satisfaction are assessed twice (t4 and t5) using a self-report questionnaire, the Everyday Stressors Index (ESI, Jäkel and Leyendecker 2008). Mothers' depressive symptoms are assessed after birth (t2) with a self-report questionnaire, which is used as a screening instrument for post-partum depression. The mothers are asked to fill in the ADS Scale (Allgemeine Depressionsskala, Hautzinger and Bailer 2002) with the help of the project staff. The cognitive and motor development of the children are assessed by trained psychologists at age 2 ( $t 4$ ) using the German version of the Bayley Scales of Infant Development II (Reuner et al. 2007). Furthermore, the emotional quality of mother-child interaction is assessed at four different times of measurement $(\mathrm{t} 2, \mathrm{t} 3, \mathrm{t} 4$ and t5). Therefore videotaped mother-child interactions are blindly rated by independent and trained psychologists with the help of the Emotional Availability Scales (Biringen Z, http://emotionalavailability.com), an observational instrument with a dyadic focus.

After the intervention, when the children enter kindergarten $(\mathrm{t} 5)$ an Integration Questionnaire (including the Hertie Belonging Scale) is applied in order to gain information on the mothers' successful participation resp. continuation of the integration/language courses and the mothers' integration. Furthermore, the mothers' satisfaction with the intervention is assessed with the help of a half standardized questionnaire in form of an interview.
In addition, the children's stress level, socio-emotional as well as language development is assessed during follow-up. Thereby the children's hair cortisol level is measured as a marker of stress when the children enter kindergarten (t5), 6 weeks afterwards as well as 1 year later (t6). Furthermore, the kindergarten teachers evaluate the children's behaviour (aggressiveness, hyperactivity, anxiety and social competence) using the Strengths and Difficulties Questionnaire (SDQ, Becker et al. 2004a; Klasen et al. 2000; Woerner et al. 2002; Woerner et al. 2004) a year after entering kindergarten (t6). Also at t6 the children's attachment security is assessed by trained and independent psychologists with the help of the Manchester Child Attachment Story Task (MCAST) (Green et al. 2000). At about the same time (t6) the children's German language development is assessed by trained linguists with the help of the LiSe-DaZ (Linguistic Language Development Survey - German as Second Language, Schulz and Tracy 2011). This is a standardized language test, which is conceptualized and standardized for children who learn German as a second language. The assessed variables and times of measurement are presented in Fig. 1.

\section{Objectives and hypotheses}

The purpose of the trial is to address the following issues:

- Differential short and long-term efficacy of two prevention programs (interventions A \& B) for children with an immigrant background and their mothers and

- Course and stability of prevention effects.

The hypotheses assume that FIRST STEPS (intervention A), which individually addresses the families' particular needs, is more effective compared to the intervention being offered by paraprofessionals (intervention B) concerning the following outcomes.

The first set of hypotheses assumes that it is more effective in terms of the children's development.

\section{Hypotheses on primary outcome}

The primary outcomes will be measured shortly after entering ( $\mathrm{t} 5$ ) and after 1 year of kindergarten ( $\mathrm{t} 6$ ).

Hypothesis 1: When entering kindergarten ( $\mathrm{t} 5)$ and after 1 year in kindergarten ( $t 6$ ) the children in intervention A show lower levels of stress compared to the children in intervention B (cortisol level measured by hair cortisol).

Hypothesis 2: After 1 year in kindergarten (t6) the children in intervention A show a better language development compared to the children in intervention B (measured 


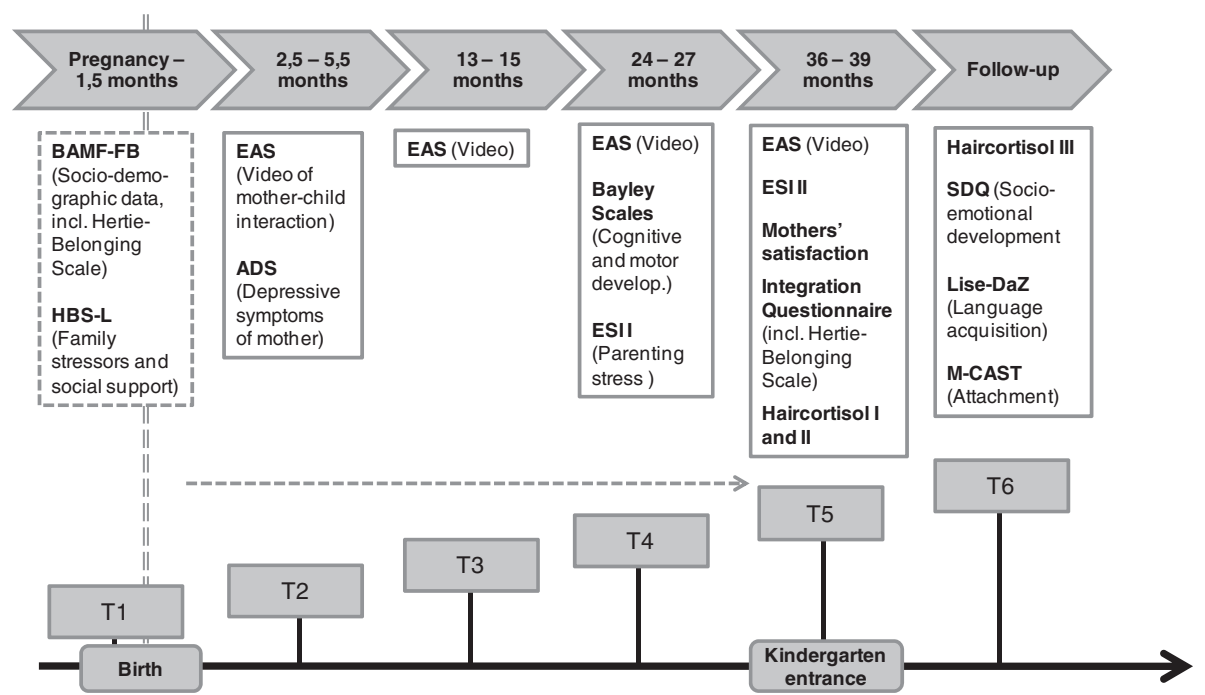

Fig. 1 Timeline of assessed variables and times of measurements. Legend: BAMF-FB: Questionnaire from the Federal Office for Migration and Refugees; Hertie-Belonging Scale: half standardized rating form - information on the mothers' integration; HBS-L: Heidelberger Belastungsskala (scale on family stressors and social support); EAS: Emotional Availability Scales; Bayley: Bayley Scales of Infant Development II; ADS: Center for Epidemiologic Studies-Depression Scale; ESI: Everyday Stressors Index; Integration Questionnaire: Half standardized rating form - information on the mothers' successful attendance of the integration course and integration (including selected BAMF items and the Hertie Belonging Scale); SDQ: Strengths and Difficulties Questionnaire; LiSe-DaZ: Linguistic Language Development Survey - German as Second Language; MCAST: Machester Child Attachment Story Task

by the Linguistic Language Development Survey German as Second Language, LiSe-DaZ).

Hypothesis 3: After 1 year in kindergarten (t6) the children in intervention A show a better socio-emotional development compared to the children in intervention B (measured by the Strengths and Difficulties Questionnaire, SDQ).

\section{Hypotheses on secondary outcome}

Hypothesis 4: At time of measurement $\mathrm{t} 4$ the children in intervention A show a better cognitive and motor development compared to the children in intervention $\mathrm{B}$ (measured by Bayley Scales of Infant Development II).

Hypothesis 5: At time of measurement t5 the children in intervention A show a better relationship to their primary caregiver (mother) compared to the children in intervention B (indicator: parent-child-interaction measured by the Emotional Availability Scales, EAS).

Hypothesis 6: The children in intervention A show after 1 year in kindergarten (t6) more often a secure attachment style (Type B) compared to the children in intervention B (measured by the Manchester Child Attachment Story Task, MCAST).

The second set of hypotheses assumes that intervention A is more effective in terms of the mothers' psychosocial integration and language development than intervention $\mathrm{B}$.

\section{Hypotheses on primary outcome}

Hypothesis 7: At time of measurement $\mathrm{t} 5$ more mothers in intervention A successfully have completed the integration course in comparison to those in intervention B (measured by the Integration Questionnaire with repeated assessment of questions of the BAMF questionnaire)

Hypothesis 8: At time of measurement $\mathrm{t} 5$ the mothers in intervention A are socially more oriented towards the host country, in comparison to those in intervention $\mathrm{B}$ (measured with the Hertie Belonging Scale).

\section{Hypotheses on secondary outcome}

Hypothesis 9: At time of measurement $\mathrm{t} 5$ the mothers in intervention A show a higher satisfaction with the intervention in comparison to the mothers who took part in intervention $\mathrm{B}$.

\section{Design}

Figure 2 summarizes the study design. The individual participants (children and their parents) were not aware of their group assignment, that is, if they were participating in intervention A (FIRST STEPS) or in intervention B. The integration courses which the women are attending are randomly assigned to the two different interventions $\mathrm{A}$ and $\mathrm{B}$, because women from the same integration course cannot be referred to different interventions (cluster-randomization). 


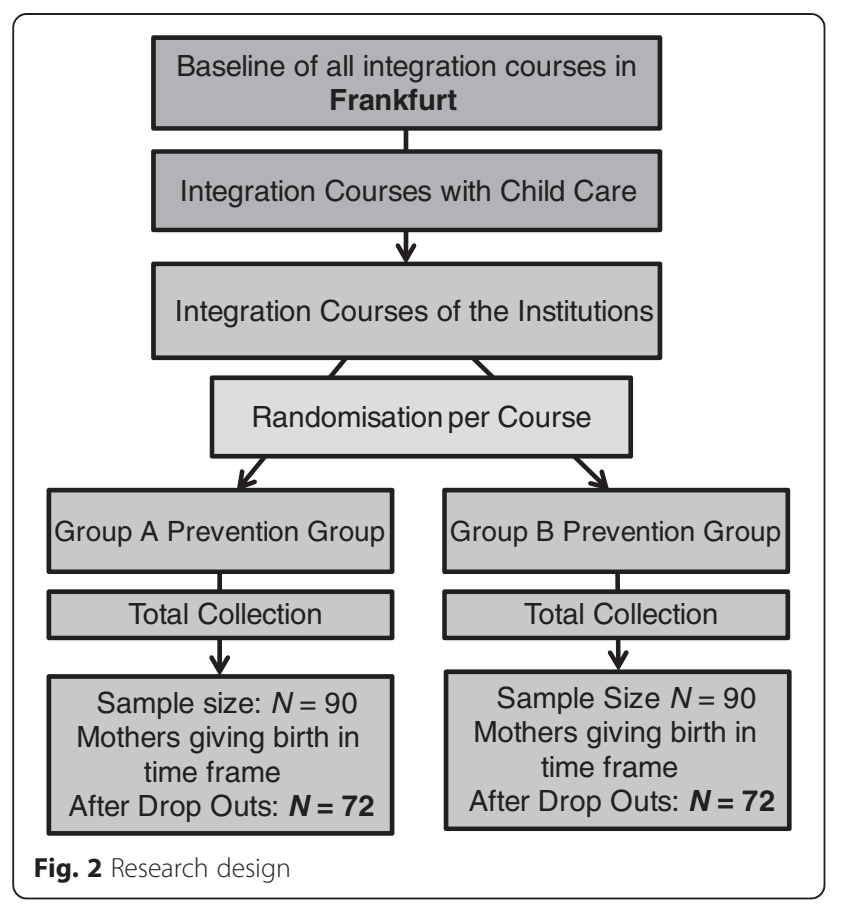

\section{Outcome}

\section{Primary outcome}

1. One primary outcome criterion is the stress level of the children measured by the children's hair cortisol level a week before kindergarten entrance, 6 weeks afterwards as well as 1 year afterwards. Measuring the concentration of cortisol in hair is a new and promising method to measure cortisol (Stadler and Kirschbaum 2012). For many years cortisol was obtained primarily from blood plasma or urine, whereas later approaches added saliva and feces for non-invasive monitoring of HPA functioning. These methods are limited in the temporal range of assessment and are only snapshots of HPA activity. However being incorporated into the growing hair, hair cortisol concentrations are assumed to provide a retrospective reflection of integrated cortisol secretion over periods of several months (Stadler and Kirschbaum 2012). Over the past years supportive evidence has accumulated regarding several fundamental characteristics of hair cortisol concentrations, including its validity as an index of long-term systemic cortisol levels both in animals (Fairbanks et al. 2011) and in human participants (Manenschijn et al. 2011), its reliability across repeated assessments (Stadler et al. 2012) and its relative robustness to a range of potential confounding influences (Stadler and Kirschbaum 2012).

2. Another primary outcome criterion is the children's knowledge of the German language, assessed a year after kindergarten entrance by a trained linguist with the help of the LiSe-DaZ (Linguistische Sprachstandsdiagnostik - Deutsch als Zweitsprache, Schulz and Tracy 2011), a standardized language test. Language acquisition is critical for the children's later school success (Gantefort and Roth 2010; Niklas et al. 2011). The LiSeDaZ enables to measure children's development in core grammatical areas and offers separate norms for multilingual children, which take into account the age of first exposure and the length of exposure to the German language (Schulz and Tracy 2011).

3. A third primary outcome criterion is the children's socio-emotional development, evaluated at kindergarten age by kindergarten teachers using the Strengths and Difficulties Questionnaire (SDQ, Becker et al. 2004a). With the help of the SDQ the following subscales can be assessed: prosocial behavior, hyperactivity, emotional problems and conduct problems with peers. The SDQ is not only a practical and economical, but also a valid and reliable questionnaire for use in the framework of a multi-dimensional behavioural assessment, and appears to be well suited for screening purposes, longitudinal monitoring of therapeutic effects, and scientific research purposes (Becker et al. 2004b; Klasen et al. 2000; Woerner et al. 2002).

4. A fourth primary outcome criteria on the part of the mothers is the mother's integration (among others mothers' successful completion of integration courses, employment/occupational comeback, interest in host country), measured by the repeated assessment of a part of the BAMF questionnaire and the Hertie Belonging Scale at the end of the intervention as indicators of successful integration.

\section{Secondary outcomes}

The secondary outcomes are:

1. The children's cognitive and motor development, assessed by trained psychologists at age $2(\mathrm{t} 4)$ using the German version of the Bayley Scales of Infant Development II (BSID, Reuner et al. 2007). The BSID II evaluates infants along three scales: a cognitive, a motor and a behaviour scale. The scales have been used extensively worldwide to assess the development of infants and are known to have high reliability and validity (Vohr et al. 2012).

2. The emotional quality of the of mother-child interaction, assessed at four different times of measurement ( $\mathrm{t} 2$ to $\mathrm{t} 5$ ) by independent and trained psychologist using the Emotional Availability Scales (EAS, http://emotionalavailability.com). The EAS allow for a detailed look at caregiver-child interactions by rating the dyad on six dimensions, four focusing on 
the parent's behaviour (sensitivity, structuring, nonintrusiveness, non-hostility) and two focusing on the child's behaviour (child responsiveness, child involvement of the caregiver). Significant findings have been reported about the positive relationship between parental EA and children's attachment security (Biringen 2000) and there is a large body of empirical research using the EA Scales (Biringen et al. 2014). It is of particular relevance that the EAS dimensions can be rated independently of the caregivers' cultural background (Biringen 2009; Biringen et al. 2014). Ziv et al. (2000) for example reported cross-cultural applicability of the EAS by examining links with attachment. In addition the EAS are an instrument that is sensitive to change related to a program of intervention (for an overview see Biringen et al. 2014).

3. The children's attachment style, assessed by trained psychologists using the MCAST (Green et al. 2000) 1 year after entering kindergarten ( $\mathrm{t} 6$ ). The MCAST, a narrative story stem task that involves playing with dolls, is a validated, structured measure that evaluates young children's attachment representations through the use of play scenarios allowing for differentiation between four overall attachment classifications: secure attachment, insecure-ambivalent attachment, insecure-avoidant attachment und insecure-disorganized attachment representations.

4. The mothers' satisfaction with the intervention, assessed after the intervention by using a halfstandardised questionnaire in form of a resumeé interview at $\mathrm{t} 5$.

\section{Sample size calculation - power analysis}

The sample size calculation resp. power analysis is based on $\alpha=0.05$ at a power of 0.80 , using pilot data concerning the number of participants in the language courses. Concerning the different primary outcomes (children's stress level, language development, socioemotional development and mothers' integration) we expect effect sizes of at least $d=0.5$. Then the sample size for analysis of variance in a RCT study would be $n=63$. But we applied a CRCT study. Therefore we have to correct the $n$ in a corrected $n^{*}$ according to the following formula introduced by Eldridge et al. (2006), providing a conservative estimate of sample size requirements for trials using cluster-level analyses weighted by cluster size:

$$
n *=\left\{1+\left[\left(1+C V^{2}\right) \times \mathrm{m}-1\right] \times I C C\right\} \times n
$$

The formula consists of the coefficient of variation $\mathrm{CV}$ for trials with unequal cluster sizes (that means with unequal sizes of language courses) and the intraclasscorrelation coefficient ICC within the clusters and the mean cluster size $m$. Using the findings of a pilot study, the estimated coefficient of variation is $C V=0.4$ (rather smaller) and the estimated intra class correlation coefficient (based on the pre-post differences including the $C V$ ) $I C C=0.1$ (rather smaller). Furthermore, we expect a mean cluster size of $m=2$ pregnant women in each course (cluster).

The corrected sample size would therefore be $n^{*}=$ $1.132 \times 63=71.32$. Thus the minimum sample size would be 72 pregnant women per treatment and resp. 36 integration courses should be selected per treatment. However under consideration of a $20 \%$ drop-out rate the corrected minimum sample size is $n^{*}=n^{*} \times 1.25=$ 90 women per treatment and thus a number of 45 courses per treatment should be selected (see Fig. 2).

\section{Representativeness of the sample and sample selection (at cluster level)}

To control for internal representativeness homogeneity tests are applied in order to verify that the two treatment groups are homogenous and in order to test for potential bias due to drop-outs or missing values. To prove that our sample is similar to the German population of immigrants that take part in integration courses nationwide (control of external representativeness) the BAMF questionnaire is applied.

\section{Randomization}

As Fig. 2 shows, randomization was performed at cluster level (integration course). A cluster-randomization was applied instead of a single randomization, because women from the same integration course should be assigned to the same intervention and not to different interventions. The statisticians, uninformed about the identity of the integration courses, used a table of random numbers for randomizing the 90 integration courses included in the study. Individual participants (children and their parents) were not aware of their group assignment, that is, if they were participating in the psychoanalytical intervention or the intervention provided by paraprofessionals.

\section{Statistical analysis}

The design is an analysis of variance design with repeated measures. The main instruments for analysis applied are Analysis of variance (ANOVA) as well as Analysis of covariance (ANCOVA) models. The main factor is the intervention group (A or B) and the most relevant secondary factor is the initial value (baseline value). All baseline characteristics will be described at the individual level. Relevant characteristics will be added if 
applicable as covariates to the models. Six main assessments encompass the treatment phase and follow-up.

\section{Ethical issues}

The Ethic Review Commission of the Federal Chamber of Psychotherapists of the State of Hessen, Germany, has approved the final study protocol and the final version of the written informed consent form. Written consent was obtained from each participating family. The trial will be carried out in keeping with local legal and regulatory requirements.

\section{Discussion}

This trial has one major goal: to compare the effectiveness of two different interventions on the development of children with an immigrant background in Germany and the integration of their mothers. Based on empirical findings it is expected that professionally supported good early relationship experience improves long-term integration of immigrant children. In a prospective randomized comparison group design the project aims at evaluating the implementation as well as the short- and long-term effectiveness of FIRST STEPS (intervention A) in comparison to an intervention being offered by paraprofessionals (intervention B). Anticipated is that supporting the earliest parent-child-interactions and parenting capacities in a professional psychoanalytically oriented intervention (A) will have a greater positive impact on the mothers' integration, on children's affective, socioemotional and cognitive development and on the quality of the parent-child relationship than the intervention provided by paraprofessionals with an immigrant background in the more open "mother-child groups" (B). We tried to reach comparable doses of intervention in the course of the 3 years of intervention for ensuring that effects would be caused by the type of intervention and would not just be a matter of more or less intervention.

In any case, number and timing of group sessions and individual contacts will be documented. In this trial, a high quality is assured by an independent assessment. Due to the high expected attrition rate in this population at risk, drop-out is thoroughly documented and respective analyses are being planned.

As mentioned before, high quality evaluation of prevention projects for young children with an immigrant background and their families have been scarce and to our knowledge an RCT comparison group design is nonexistent in Germany. Thus the study has the status of a model project. If the prevention offers prove to be effective and sustaining, the empirically based prevention programs may be implemented in other German cities and migrant populations as well. Thus the study will prove to have a practical and political relevance.

\section{Endnotes}

${ }^{1}$ In $201048 \%$ of children living in families with a migrant background grew up exposed to at least one situation of risk such as unemployed, low-income or educationally disadvantaged parents.

${ }^{2}$ IDEA = Individual Development and Adaptive Education of Children at Risk; http://www.idea-frankfurt.eu/ de.

${ }^{3}$ At this point about 120 researchers from different disciplines such as pedagogics, psychology, psychoanalysis, neurosciences and different subject didactics work together at the center. Around 50 different research projects are realized.

${ }^{4}$ Landes-Offensive zur Entwicklung Wissenschaftlichökonomischer-Exzellenz (Political strategy of the State of Hessen for strengthening the development of scientific and economic excellence)

${ }^{5}$ Child and youth-psychoanalyst Claudia BurkhardtMußmann (in Frankfurt) and Rose Alheim (in Berlin)

${ }^{6}$ Self-organized open mother-child groups have become a common form of similar early prevention projects in Germany (Friedrich \& Siegert 2009).

${ }^{7}$ This survey gives a broad overview over the personal background of the participants, the already acquired languages and especially German language skills, job and educational issues and their life in Germany. It has been used in a large scale study for the population of the integration courses in Germany.

\section{Abbreviations}

ADS: Allgemeine Depressionsskala; ANCOVA: Analysis of covariance; ANOVA: Analysis of variance; BAMF: Bundesamt für Migration und Flüchtlinge (German Federal Office for Migration and Refugees); BSID: Bayley Scales of Infant Development; DIPF: Deutsches Institut für internationale pädagogische Forschung (German Institute for International Educational Research); EAS: Emotional Availability Scales; ESI: Everyday Stressors Index; HBSL: Heidelberger Belastungsskala (scale on family stressors and social support); IDeA: Individual Development and Adaptive Education of Children at Risk; LiSe-DaZ: Linguistische Sprachstandserhebung - Deutsch als Zweitsprache (Linguistic Language Development Survey - German as Second Language); LOEWE: Landesoffensive zur Entwicklung wissenschaftlich-ökonomischer Exzellenz (Political strategy of the State of Hessen for strengthening the development of scientific and economic excellence); MCAST: Manchester Child Attachment Story Task; SDQ: Strengths and Difficulties Questionnaire; SFI: Sigmund-Freud-Institut.

\section{Competing interests}

The authors declare that they have no competing interests.

\section{Authors' contributions}

MLB is the Principal Investigator for this trial. The study transcript was developed by MLB (design, concept for intervention "First Steps"), JLV (design, assessments), and BR (statisticians). JLV, CR, AB, KF and MLB managed the study, supervised research staff, enrollment and the follow-up of study participants. $J L V, C R, A B, K F$ and MLB drafted this manuscript. BR analyzed study data as independent statistician. JLV, CR, AB, KF, BR and MLB contributed equally to writing this manuscript and approving the final version.

\section{Acknowledgements}

We gratefully acknowledge the parents and their children in the FIRST STEPS project. We would like to thank our following colleagues and co-workers in conducting the FIRST STEPS study: Claudia Burkhardt-Mußmann, Angelika 
Wolff from the Ann-Freud-Institut, the AWO Hessen Süd, infrau e.V., ASB Lehrerkooperative gGmbH, Hertie Foundation and IDeA Centre. We would particularly like to thank our consultants Prof. Robert N. Emde and Dr. Henri Parens for accompanying the research process and Prof. Zeynep Biringen for introducing the EAS to our research team.

\section{Funding}

First Steps is carried out by the Sigmund-Freud-Institut and the Anna-FreudInstitut in the Center for Research on Individual Development and Adaptive Education of Children at Risk (IDeA) which is supported by the "Landesoffensive zur Entwicklung wissenschaftlich-ökonomischer Exzellenz (LOEWE)" of the State of Hessen, Germany (see: http://www.idea-frankfurt.eu/de), and additionally funded by the Bundesamt für Migration und Flüchtlinge, by the state of Hessen, Regierungspräsidium Darmstadt, by a private donator and the Hertie Foundation.

\section{Author details}

'Sigmund-Freud-Institut, Frankfurt/Main, Germany, University of Kassel, Kassel, Germany. ${ }^{2}$ Institute for Statistics, Maximilian University of Munich, Munich, Germany.

Received: 29 January 2015 Accepted: 16 June 2015

Published online: 03 July 2015

\section{References}

Autorengruppe Bildungsberichterstattung. (2012). Bildung in Deutschland 2012. Ein indikatorengestützter Bericht mit einer Analyse zur kulturellen Bildung im Lebenslauf. Bielefeld: Bertelsmann.

Aviezer, O., Resnick, G., Sagi, A., \& Gini, M. (2002). School competence in young adolescents: links to early attachment relationships beyond concurrent selfperceived competence and representations of relationships. International Journal of Behavioral Development, 26, 397-409.

Batista-Pinto Wiese, E. (2010). Culture and migration: Psychological trauma in children and adolescents. Traumatology, 16(Suppl 4), 142-152.

Becker, A., Hagenberg, N., Roessner, V., Woerner, W., \& Rothenberger, A. (2004a). Evaluation of the self-reported SDQ in a clinical setting: do self-reports tell us more than ratings by adult informants? European Child and Adolescent Psychiatry, 13(Suppl 2), I117-24.

Becker, A., Woerner, W., Hasselhorn, M., Banaschewski, T., \& Rothenberger, A. (2004b). Validation of the parent and teacher SDQ in a clinical sample. European Child \& Adolescent Psychiatry, 13(Suppl 2), II11-\|16.

Berlin, L., Zeanah, C. H., \& Lieberman, A. F. (2008). Prevention and Intervention Programs for Supporting Early Attachment Security. In J. Cassidy \& P. R. Shaver (Eds.), Handbook of Attachment: Theory, Research and Clinical Applications (2nd ed., pp. 745-761). New York/London: Guilford Press.

Bion, W. R. (1963). Elemente der Psychoanalyse. Suhrkamp: Frankfurt/Main.

Biringen, Z. (2000). Emotional Availability: Conceptualization and Research Findings. American Journal of Orthopsychiatry, 70(Suppl 1), 104-114.

Biringen, Z. (2009). The Universal Language of Love. Assessing Relationships Through the Science of Emotional Availability. Emotional Availability: Boulder, CO.

Biringen Z. The Emotional availability (EA) scales manual, $4^{\text {th }}$ edition. [http:// emotionalavailability.com]

Biringen, Z., Derscheid, D., Vliegen, N., Closson, L., \& Easterbrooks, M. (2014). Emotional availability (EA): Theoretical background, empirical research using the EA Scales, and clinical applications. Developmental Review, 34(Suppl 2), 114-167.

Boudon, R. (1974). Education, Opportunity, and Social Inequality. Changing Prospects in Western Society. New York: Wiley \& Sons.

Bowlby, J. (1969). Attachment and Loss: Volume 1: Attachment. New York: Basic Books.

Bundesministerium für Arbeit und Soziales (BMAS). Lebenslagen in Deutschland. Der 4. Armuts- und Reichtumsbericht der Bundesregierung. [https:// www.bmas.de/SharedDocs/Downloads/DE/PDF-Publikationen-DinA4/a334-4armuts-reichtumsbericht-2013.pdf? blob=publicationFile].

Cassidy, J., \& Shaver, P. R. (Eds.). (2008). Handbook of Attachment: Theory, Research, and Clinical Applications (2nd ed.). London: The Guilford Press.

Cooney S, Small S, O'Connor C. Strategies for recruiting and retaining participants in prevention programs. University of Wisconsin-Extension, Madison, WI, What Works, Wisconsin - Research to Practice Series, Issue 2; 2007.

DeKlyen, M., \& Greenberg, M. T. (2008). Attachment and Psychopathology in Childhood. In J. Cassidy \& P. R. Shaver (Eds.), Handbook of Attachment: Theory,
Research, and Clinical Applications (2nd ed., pp. 637-665). New York: Guilford Press.

Doherty, P., Stott, A., \& Kinder, K. (2004). Delivering Services to Hard to Reach Families in On Track Areas: Definition, Consultation and Needs Assessment In Development and Practice Report No. 15. London: Home Office.

Eldridge, S., Ashby, D., \& Kerry, S. (2006). Sample size for cluster randomized trials: effect of coefficient of variation of cluster size and analysis method. International Journal of Epidemiology, 35, 1292-1300.

Emde, R. N., \& Leuzinger-Bohleber, M. (2014). Early Parenting and Prevention of Disorder: Psychoanalytic Research at Interdisciplinary Frontiers. London: Karnac Books.

Emde, R. N., \& Robinson, J. L. (2000). Guilding Principles for a Theory of Early Intervention. A Developmental-Psychoanalytic Perspective. In J. P. Shonkoff \& S. J. Meisels (Eds.), Handbook of Early Childhood Intervention (pp. 160-178). New York: Cambridge University Press.

Fairbanks, L. A., Jorgensen, M. J., Bailey, J. N., Breidenthal, S. E., Grzywa, R., \& Laudenslager, M. L. (2011). Heritability and genetic correlation of hair cortisol in vervet monkeys in low and higher stress environments. Psychoneuroendocrinology, 36(Suppl 8), 1201-1208.

Fazel, M., Wheeler, J., \& Danesh, J. (2005). Prevalence of serious mental disorder in 7000 refugees resettled in western countries: a systematic review. The Lancet, 365, 309-1314.

Fearon, R. M. P., Bakermans-Kranenburg, M. J., van IJzendoorn, M. H., Lapsley, A. M., \& Roisman, G. I. (2010). The significance of insecure attachment and disorganization in the development of children's externalizing behavior: a meta-analytic study. Child Development, 81, 435-456.

Fonagy, P., Gergely, G., Jurist, E. L., \& Target, M. (2002). Affect Regulation, Mentalization, and the Development of the Self. New York: Other Press.

Friedrich, L., \& Siegert, M. (2009). Förderung des Bildungserfolgs von Migranten: Effekte familienorientierter Projekte. Abschlussbericht zum Projekt Bildungserfolge bei Kindern und Jugendlichen mit Migrationshintergrund durch Zusammenarbeit mit den Eltern. Working Paper 24. Nürnberg: Bundesamt für Migration und Flüchtlinge.

Gantefort, C., \& Roth, H. J. (2010). Sprachdiagnostische Grundlagen für die Förderungbildungssprachlicher Fähhigkeiten. Zeitschrift für Erziehungswissenschaft, 13(Suppl 4), 573-591.

Green, J., \& Goldwyn, R. (2002). Attachment disorganisation and psychopathology: new findings in attachment research and their potential implications for developmental psychopathology in childhood. Journal of Child Psychology and Psychiatry, 43(Suppl 7), 835-846.

Green, J., Stanley, C., Smith, V., \& Goldwyn, R. (2000). A new method of evaluating attachment representations in young school-age children: the Manchester child attachment story task. Attachment \& Human Development, 2, 48-70.

Hautzinger, M., \& Bailer, M. (2002). ADS - Allgemeine Depressions Skala. In E. Brähler, J. Schumacher, \& B. Strauß (Eds.), Diagnostische Verfahren in der Psychotherapie (pp. 25-27). Göttingen: Hogrefe.

Hölling, H., Kurth, B., Rothenberger, A., Becker, A., \& Schlack, R. (2008). Assessing psychopathological problems of children and adolescents from 3 to 17 years in a nationwide representative sample: Results of the German health interview and examination survey for children and adolescents (KiGGS). European Child \& Adolescent Psychiatry, 17(Suppl 1), 34-41. doi:10.1007/ s00787-008-1004-1.

Holodynski, M., Stallmann, F., \& Seeger, D. (2007). Bildungsbedeutung von Eltern, Familien und anderen Bezugspersonenfür Kinder. Expertise im Auftrag der Enquetekommission "Chancen für Kinder"des Landtags NRW. Düsseldorf: Landtag NRW.

Jäkel, J., \& Leyendecker, B. (2008). Tägliche Stressfaktoren und Lebenszufriedenheit türkischstämmiger Mütter in Deutschland. Zeitschrift für Gesundheitspsychologie, 16(Suppl 1), 12-21.

King, V. (2007). Identitätssuche und Genereationsdynamiken in der Adoleszenz. In J. Wiesse \& P. Joraschky (Eds.), Identitäten im Verlauf des Lebens (pp. 34-51). Goettingen: Vandenhoeck \& Ruprecht.

Klasen, H., Woerner, W., Wolke, D., Meyer, R., Overmeyer, S., Kaschnitz, W., Rothenberger, A., \& Goodman, R. (2000). Comparing the German versions of the Strengths and Difficulties Questionnaire (SDQ-Deu) and the Child Behavior Checklist. European Child and Adolescent Psychiatry, 9, 271-276.

Korntheuer, P., Lissmann, I., \& Lohaus, A. (2010). Bindungssicherheit und die Entwicklung von Sprache und Kognition. Psychologie in Erziehung und Unterricht, 57(Suppl 1), 1-20.

Kurth, B.-M., \& Schaffrath Rosario, A. (2007). Die Verbreitung von Übergewicht und Adipositas bei Kindern und Jugendlichen in Deutschland - Ergebnisse 
des bundesweiten Kinder- und Jugendgesundheitsurveys (KiGGS). Bundesgesundheitsblatt, 5(6), 736-74.

Leuzinger-Bohleber, M. (2009). Fruehe Kindheit als Schicksal? Trauma, Embodiment, Soziale Desintegration, Psychoanalytische Perspektiven. Stuttgart: Kohlhammer.

Leuzinger-Bohleber, M. (2012). Changes in Dreams - From a Psychoanalysis with a Traumatised, Chronic Depressed Patient. In P. Fonagy, H. Kächele, M. Leuzinger-Bohleber, \& D. Taylor (Eds.), The Significance of Dreams: Bridging Clinical and Extraclinical Research in Psychoanalysis (pp. 49-85). London: Karnac Books.

Leuzinger-Bohleber, M., Brandl, Y., Hau, S., Aulbach, L., Caruso, B., Einert, K. M., Glindemann, O., Göppel, G., Hermann, P., Hesse, P., Heumann, J., Karaca, G., König, J., Lendle, J., Rüger, B., Schwenk, A., Staufenberg, A., Steuber, S., Uhl, C Vogel, J., Waldung, C., Wolff, L., \& Hüther, G. (2006). Die Frankfurter Präventionsstudie. Zur psychischen und psychosozialen Integration von verhaltensauffälligen Kindern (insbesondere von ADHS) im Kindergartenalter ein Arbeitsbericht. In M. Leuzinger-Bohleber, Y. Brandl, \& G. Hüther (Eds.), ADHS - Frühprävention statt Medikalisierung. Theorie, Forschung, Kontroversen. (Schriften des Sigmund-Freud-Instituts; Reihe 2: Psychoanalyse im interdisziplinären Dialog, Band 4) (pp. 238-269). Göttingen: Vandenhoeck \& Ruprecht

Leuzinger-Bohleber, M., Fischmann, T., \& Lebiger-Vogel, J. (2009). Weißt du, manchmal möchte ich nicht mehr leben...". Frühprävention als Stärkung der Resilienz gefährdeter Kinder? Ergebnisse aus der Frankfurter Präventionsstudie. In R. Haubl, F. Dammasch, \& H. Krebs (Eds.), Riskante Kindheit. Psychoanalyse und Bildungsprozesse (pp. 87-128). Göttingen: Vandenhoeck \& Ruprecht.

Leuzinger-Bohleber, M., Läzer, K. L., Pfennig-Meerkötter, N., Fischmann, T., Wolff, A., \& Green, J. (2011). Psychoanalytic treatment of ADHD children in the frame of two extraclinical studies: the Frankfurt Prevention Study and the EVA Study. Journal of Infant Child and Adolescent Psychotherapy, 10, 32-50.

Lösel, F., Schmucker, M., Plankensteiner, B., \& Weis, M. (2006). Bestandsaufnahme und Evaluation von Angeboten im Elternbildungsbereich. Abschlussbericht. Erlangen: Bundesamt für Migration und Flüchtlinge.

Lyons-Ruth, K., Alpern, L., \& Repacholi, B. (1993). Disorganized infant attachment classification and maternal psychosocial problems as predictors of hostileaggressive behavior in the preschool classroom. Child Development, 64, 572-585.

Manenschijn, L., Koper, J. W., Lamberts, S. W. J., \& van Rossum, E. F. C. (2011). Evaluation of a method to measure long term cortisol levels. Steroid, 76, 1032-1036.

Meurs, P., Jullian, G., \& Vliegen, N. (2006). Culture Sensitive Developmental Guidance for Immigrant Families with Pre-School Children. Pathways to resilience within The First Steps prevention programme. In M. C. Foblets, J. Vrielink, \& J. Billiet (Eds.), Multiculturalisme ontleed. Een staalkaart van onderzoek aan de K.U. Leuven (pp. 255-285). Leuven: Universitaire Pers.

Moss, E., Cyr, C., \& Dubois-Comtois, K. (2004). Attachment at early school age and developmental risk: examining family contexts and behavior problems of controlling-caregiving, controlling-punitive, and behaviorally disorganized children. Developmental Psychology, 40(Suppl 4), 519-532.

Niklas, F., Schmiedeler, S., Pröstler, N., \& Schneider, W. (2011). Die Bedeutung des Migrationshintergrunds, des Kindergartenbesuchs sowie der Zusammensetzung der Kindergartengruppe für sprachliche Leistungen von Vorschulkindern. Zeitschrift für Pädagogische Psychologie, 25(Suppl 2), 115-130.

Olds, D. L., Sadler, L., \& Kitzman, H. (2008). Programs for parents of infants and toddlers: recent evidence from randomized trials. Journal of Child Psychology and Psychiatry, 48(Suppl 3-4), 355-391.

Parens, H., Scattergood, E., \& Petersen, K. (1995). Kindliche Aggressionen. Wie wir Grenzen setzen und den konstruktiven Umgang mit Gefühlen unterstützen können. Kösel: München.

Rattay, P., Lampert, T., Neuhauser, H., \& Ellert, U. (2012). Bedeutung der familialen Lebenswelt für die Gesundheit von Kindern und Jugendlichen Ergebnisse des Kinder- und Jugendgesundheitssurveys (KiGGS). Zeitschrift Für Erziehungswissenschaft, 15(1), 145-170. doi:10.1007/s11618-012-0261-4.

Reuner, G., Rosenkranz, J., Pietz, J., \& Horn, R. (2007). Bayley Scales of Infant Development, Second Edition (Bayley II) - Deutsche Fassung. Frankfurt/M: Pearson Assesment.

Rother N. Bundesamt für Migration und Flüchtlinge (BAMF). Fragebogen Integrationspanel. [http://www.bamf.de/SharedDocs/Anlagen/DE/ Publikationen/WorkingPapers/wp19-

Integrationspanel.pdf?_blob=publicationFile]

Sachverständigenrat deutscher Stiftungen für Integration und Migration (SVR) GmbH: Deutschlands Wandel zum modernen Einwanderungsland. Jahresgutachten 2014 mit Integrationsbarometer. [http://www.Svrmigration.de/wp-content/uploads/2014/11/SVR_JG_2014_WEB.pdf]
Schechter, D. S., \& Rusconi Serpa, S. (2014). Understanding How Traumatised Mothers Process Their Toddlers' Affective Communication Under Stress: Towards Preventive Intervention for Families at High Risk for Intergenerational Violence. In R. N. Emde \& M. Leuzinger-Bohleber (Eds.), Early Parenting and Prevention of Disorder: Psychoanalytic Research at Interdisciplinary Frontiers (pp. 90-117). London: Karnac Books.

Schulz, P., \& Tracy, R. (2011). Linguistische Sprachstandserhebung - Deutsch als Zweitsprache (LiSe-DaZ). Hogrefe Verlag: Göttingen.

Solomon, J., George, C., \& De Jong, A. (1995). Children classified as controlling at age six: evidence of disorganized representational strategies and aggression at home and at school. Development and Psychopathology, 7(Suppl 3), 447-463.

Sroufe, L. A., Egeland, B., Carlson, E. A., \& Collins, W. A. (2005). The Development of the Person: The Minnesota Study of Risk and Adaptation from Birth to Adulthood. New York: Guilford Press.

Stacks, A. M., \& Oshio, T. (2009). Disorganized attachment and social skills as indicators of Head Start children's school readiness skills. Attachment \& Human Development, 11(Suppl 2), 143-164.

Stadler, T., \& Kirschbaum, C. (2012). Analysis of cortisol in hair - state of the art and future directions. Brain, behavior, and immunity. Brain Behavior and Immunity, 26(Suppl 7), 1019-1029.

Stadler, T., Steudte, S., Miller, R., Skoluda, N., Dettenborn, L., \& Kirschbaum, C. (2012). Intraindividual stability of hair cortisol concentrations. Psychoneuroendocrinology, 37, 602-610.

Stasch M. Heidelberger Belastungsskala (HBS-L) (2009). Universitätsklinikum Heidelberg; http://www.keinerfaelltdurchsnetz.de/files/9214/0776/4143/ HBS_13.03.09.pdf. Accessed 20 Mai 2015.

Stern, D. N. (1985). The Interpersonal World of Infant. A View from Psychoanalysis and Developmental Psychology. New York: Basic Books.

Thompson, R. A. (2008). Early Attachment and Later Development: Familiar Questions, New Answers. In J. Cassidy \& P. R. Shaver (Eds.), Handbook of Attachment (2nd ed., pp. 348-365). New York: Guilford.

Van IJzendoorn, M. H., Dijkstra, J., \& Bus, A. G. (1995). Attachment, intelligence, and language: a meta-analysis. Social Development, 4, 115-128.

Vohr, B. R., Stephens, B. E., Higgins, R. D., Bann, C. M., Hintz, S. R., Das, A., et al. (2012). Are outcomes of extremely preterm infants improving? impact of Bayley assessment on outcomes. Journal of Pediatrics, 161, 222-228.

Woerner, W., Becker, A., Friedrich, C., Klasen, H., Goodman, R., \& Rothenberger, A. (2002). Normierung und Evaluation der deutschen Elternversion des Strengths and Difficulties Questionnaire (SDQ): Ergebnisse einer repräsentativen Felderhebung. Zeitschrift für Kinder- und Jugendpsychiatrie und Psychotherapie, 30, 105-112.

Woerner, W., Becker, A., \& Rothenberger, A. (2004). Normative data and scale properties of the German parent SDQ. European Journal of Child and Adolescent Psychiatry, 13(Suppl 2), 11-16.

Ziv, Y., Aviezer, O., Gini, M., Sagi, A., \& Koren-Karie, N. (2000). Emotional availability in the mother-infant dyad as related to the quality of infant-mother attachment relationship. Attachment \& Human Development, 2, 149-169.

\section{Submit your next manuscript to BioMed Central and take full advantage of:}

- Convenient online submission

- Thorough peer review

- No space constraints or color figure charges

- Immediate publication on acceptance

- Inclusion in PubMed, CAS, Scopus and Google Scholar

- Research which is freely available for redistribution 